\title{
Konsepsi Siswa Tentang Kelembaman untuk Konteks
}

\section{Berbeda}

\author{
Uyun, Jusman Mansyur, dan Supriyatman \\ setiawanuyun@gmail.com \\ Program Studi Pendidikan Fisika FKIP Universitas Tadulako \\ Jl. Soekarno Hatta Km. 9 Kampus Bumi Tadulako Tondo Palu - Sulawesi Tengah
}

\begin{abstract}
Abstrak - Penelitian ini menggunakan pendekatan deskriptif kualitatif yang bertujuan untuk mendeskripsikan konsepsi siswa tentang kelembaman untuk konteks berbeda. Penelitian ini dilakukan di SMA Negeri 1 Palu. Subyek penelitian adalah siswa kelas XI A yang terdiri dari 30 siswa. Instrumen pengumpulan data yang digunakan yaitu tes seleksi responden, tes essay, dan wawancara. Tes seleksi responden terdiri dari 20 butir soal yang diberikan kepada 30 siswa untuk menentukan 9 responden serta tes essay terdiri dari 5 butir soal yang diberikan kepada 9 responden yang terpilih. Berdasarkan penelitian, hasilnya menunjukkan konsepsi siswa pada materi kelembaman untuk konteks yang berbeda pada responden kategori tinggi masih tergolong rendah, untuk responden kategori sedang juga masih tergolong rendah, dan untuk untuk responden kategori rendah tergolong sedang.
\end{abstract}

Kata Kunci: Konsepsi, Kelembaman

\section{PENDAHULUAN}

Fisika merupakan ilmu pengetahuan yang paling mendasar, karena berhubungan dengan perilaku dan struktur benda [1]. Sebagian besar siswa menganggap fisika adalah mata pelajaran yang sulit dipahami, lebih-lebih pada materi yang bersifat abstrak. Kenyataannya belajar fisika menuntut lebih banyak pemahaman dari pada penghafalan.

Secara umum, penelitian dalam bidang ini dikelompokkan menjadi tiga topik besar, yaitu mengidentifikasi miskonsepsi yang sering terjadi dikalangan siswa, mengembangkan dan mengevaluasi pembelajaran untuk mengatasi miskonsepsi, dan menjelaskan struktur pengetahuan dalam memori siswa [2]. Di antara ketiga topik penelitian tersebut, penelitian tentang miskonsepsi, atau pemahaman konseptual siswa secara umum, merupakan topik yang paling banyak dilakukan.

Penyebab ada atau ditemukannya kesalahan konsep (miskonsepsi) pada siswa dapat diketahui dengan cara mendeteksi yang prakonsepsi dimilikinya. Untuk dapat mendeteksinya, harus digunakan suatu instrumen khusus yaitu tes diagnostik yang dapat mengungkap adanya kesalahan konsep dari masing-masing subjek [3].

Secara garis besar, penyebab miskonsepsi pada siswa/mahasiswa dapat berasal dari siswa/mahasiswa sendiri, guru, buku teks, konteks, dan metode mengajar [4].

Identifikasi pemahaman konsep fisika pada materi kelembaman perlu dilakukan agar kita tahu konsep yang sudah dibangun oleh siswa dan dapat dilakukan perlakuan yang tepat kepada siswa. Sejauh ini hanya sedikit penelitian yang mengkaji pemahaman konsep siswa pada materi kelembaman. Padahal, materi kelembaman merupakan salah satu bagian penting dalam fisika yang harus dikuasai oleh siswa.

Penelitian tentang konsepsi yang telah ada yaitu konsep kinematika gerak lurus [5] penyebab konsepsi siswa rendah yakni lebih besar mengalami miskonsepsi dalam pengalaman sehari-hari. Pada rangkaian listrik arus searah [6] penyebab pemahaman konsepsi siswa rendah yaitu miskonsepsi dan tidak memahami konsep yang ada. Khusus untuk penelitian pada konsep kelembaman hanya sedikit terdapat penelitian yang dilakukan tentang konsep tersebut.

\section{METODE PENELITIAN}

Penelitian ini menggunakan pendekatan deskriptif-kualitatif yang datanya berupa faktafakta yang ada. Menurut Sukmadinata [7] bahwa penelitian deskriptif ditujukan untuk mendeskripsikan atau menggambarkan fenomena-fenomena yang ada, baik fenomena yang bersifat alamiah ataupun rekayasa manusia. Penelitian ini mendeskripsikan konsepsi siswa tentang kelembaman untuk konteks berbeda menggunakan soal essay yang didukung dengan wawancara.

Subjek penelitian ini adalah siswa kelas XI IPA 1 SMA Negeri 1 Palu Tahun Ajaran 2017/2018 yang berjumlah 30 siswa dan responden dalam penelitian ini berjumlah 9 siswa. 
Responden dipilih berdasarkan nilai TSR yang diperoleh yakni 3 siswa dengan nilai tertinggi, 3 siswa yang memperoleh nilai sedang dipilih secara random, dan 3 siswa dengan perolehan nilai terendah.

Hasil pengolahan data, nilai rata-rata yang diperoleh adalah 59,17 dan nilai standar deviasi adalah 8,98. Berdasarkan kategori tersebut dipilih 3 (tiga) orang dari masing-masing kategori tinggi, sedang, dan rendah yang akan diberikan tes essay serta diwawancarai dengan mempertimbangkan hasil jawaban yang diberikan pada tes essay konsepsi siswa. Berikut dapat diamati pada Table 1.

\begin{tabular}{ccc}
\multicolumn{3}{c}{ TABEL 1} \\
\hline No & Inisial Siswa & Kategori \\
\hline 1 & R-07 & Tinggi \\
2 & R-10 & Tinggi \\
3 & R-26 & Tinggi \\
4 & R-14 & Sedang \\
5 & R-18 & Sedang \\
6 & R-23 & Sedang \\
7 & R-08 & Rendah \\
8 & R-15 & Rendah \\
9 & R-29 & Rendah \\
\hline
\end{tabular}

\section{HASIL DAN PEMBAHASAN}

Topik utama penelitian yakni untuk mendeskripsikan konsepsi tentang kelembaman untuk konteks berbeda. Perangkat instrumen yang digunakan dalam penelitian ini yaitu TSR, tes essay, dan wawancara.

Pengumpulan data dilakukan melalui pemberian tes kepada responden yang telah terpilih sebagai subjek penelitian. Namun sebelumnya telah dilakukan observasi untuk mengetahui situasi tempat penelitian dan melakukan kesepakatan dengan guru kemudian disampaikan kepada siswa tentang waktu yang tepat untuk pelaksanaan tes dan waktu wawancara.

Pada saat responden menjawab tes yang diberikan, interaksi antara responden dan peneliti berlangsung secara komunikatif. Selain itu, responden juga bersedia memberikan informasi terhadap hasil tes yang telah dilakukan melalui kegiatan wawancara.

\section{$>\quad$ Responden Kategori Tinggi}

Responden dengan kategori tinggi yakni RT-07, RT-10, dan RT-26 dapat mengerjakan soal konsep kelembaman untuk konsep berbeda. Hasilnya menunjukan untuk responden RT-07 menjawab salah untuk konsep kelembaman pada seorang pengamat di atas tanah yang mengamati benda di dalam kereta api, peristiwa mobil A dan B yang memiliki kecepatan yang tetap, dan benda yang memiliki ukuran sama tetapi yang satu terbuat dari kayu dan yang lain terbuat dari besi. Berikut potongan jawaban responden dapat disajikan pada Gbr 1, Gbr 2, dan Gbr 3.

\section{Percepatan berda sama dengon Percepatan kereta}

Gbr 1. Kutipan jawaban RT-07 tentang konsep kelembaman.

$$
\begin{aligned}
& \text { Mobil A lebila besar gajanya } \\
& \text { karena mobil A memiliki } \\
& \text { kecepatan yang lebih besar }
\end{aligned}
$$

Gbr 2. Kutipan jawaban RT-07 tentang konsep kelembaman.

$$
\begin{aligned}
& \text { Hal tersebut terjadi karena } \\
& \text { Besi memiliki massa jenis yang } \\
& \text { leblh besar sehingga kita membutuhion } \\
& \text { gaya yang lebih besar, dibandingkan } \\
& \text { kayo memilika massa jenis yang } \\
& \text { keal sehingga gaya yang } \\
& \text { dibutuhkan keali. }
\end{aligned}
$$

Gbr 3. Kutipan jawaban RT-07 tentang konsep kelembaman.

Dinyatakan bahwa RT-07 kurang memahami maksud untuk konsep kelembaman dari masingmasing konteks di atas. Hal itu disebabkan karena RT-07 tidak menguasai konsep kelembaman. Hasil yang diperoleh sesuai dengan penelitian yang dilakukan sebelumnya oleh Yerdelen dan Damar [8] yang menyimpulkan bahwa tidak satupun dari siswa SMA yang benarbenar memahami konsep kelembaman.

Untuk responden RT-10 menjawab salah untuk konsep kelembaman pada peristiwa mobil A dan $B$ yang memiliki kecepatan yang tetap, dan benda yang memiliki ukuran sama tetapi yang satu terbuat dari kayu dan yang lain terbuat dari besi. Berikut potongan jawaban responden dapat disajikan pada Gbr 4, dan Gbr 5.

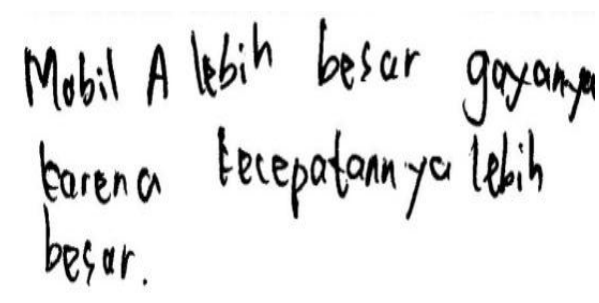

Gbr 4. Kutipan jawaban RT-10 tentang konsep kelembaman. 


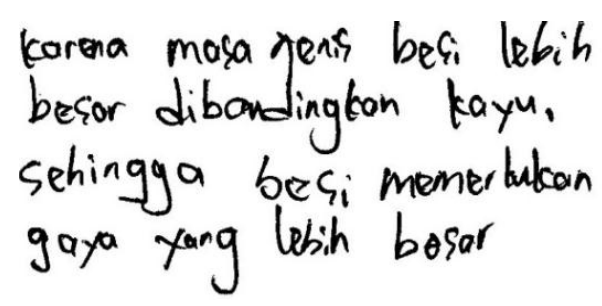

Gbr 5. Kutipan jawaban RT-10 tentang konsep kelembaman.

Dari kutipan jawaban dapat dinyatakan bahwa RT-10 kurang memahami konsep kelembaman sehingga menyebabkan terjadi kekeliruan dalam menjawab soal. Kemungkinan disebabkan oleh kurangnnya pemahaman terhadap soal konsep. Hasil yang diperoleh sesuai dengan penelitian yang dilakukan oleh Kevin [9] bahwa penyebab dari pemahaman konsepsi siswa yang rendah yaitu siswa susah untuk memahami soal yang berhubungan dengan pemahaman konsep.

Hasilnya menunjukan untuk responden RT-26 menjawab salah untuk konsep kelembaman pada seorang pengamat di atas tanah yang mengamati benda di dalam kereta api, peristiwa mobil A dan B yang memiliki kecepatan yang tetap, dan benda yang memiliki ukuran sama tetapi yang satu terbuat dari kayu dan yang lain terbuat dari besi. Berikut potongan jawaban responden dapat disajikan pada $\mathrm{Gbr} 6, \mathrm{Gbr} 7$, dan Gbr 8.

\section{Percepatan benda tarsebut sama dengan percepatan kereta torb.}

Gbr 6. Kutipan jawaban RT-26 tentang konsep kelembaman.

$$
\text { Mobil A, }
$$

Gbr 7. Kutipan jawaban RT-26 tentang konsep kelembaman.

Karena masga besi lebih

berat dare pada kaya walaupun redua benda

tarsebut mempunyai ucuran yang sam $a$.

Gbr 8. Kutipan jawaban RT-26 tentang konsep kelembaman.

Dari kutipan jawaban dapat dinyatakan bahwa RT-26 kurang memahami maksud untuk konsep kelembaman dari masing-masing konteks diatas. Hal itu disebabkan karena RT-26 tidak menguasai konsep kelembaman. Hasil yang diperoleh sesuai dengan penelitian yang dilakukan sebelumnya oleh Yerdelen dan Damar [8] yang menyimpulkan bahwa tidak satupu dari siswa SMA yang benar-benar memahami konsep kelembaman.

\section{$>\quad$ Responden Kategori Sedang}

Responden kategori sedang RS-14, RS-18, dan RS-23 dapat mengerjakan soal konsep kelembaman untuk konsep berbeda. Hasilnya menunjukan untuk responden RS-14 menjawab salah untuk konsep kelembaman pada saat kita mengendarai motor yang sedang bergerak dan direm secara tiba-tiba, seorang pengamat di atas tanah yang mengamati benda di dalam kereta api, dan peristiwa mobil A dan B yang memiliki kecepatan yang tetap. Berikut potongan jawaban responden dapat disajikan pada Gbr 9, Gbr 10, dan Gbr 11.

$$
\begin{aligned}
& \text { Berhuluongan dengan momen inersia. } \\
& \text { kenapa tiba? orang yang sedany } \\
& \text { membawa rator ketilia direm } \\
& \text { secara tiba? dia terdorong } \\
& \text { hedopan dan hita motor dijalankan } \\
& \text { dia terdorong Whelakang, Seseorang } \\
& \text { tershout momilili momen inersia } \\
& \text { arlinga orang tershot sodah nyaman } \\
& \text { Pada Posisinya. }
\end{aligned}
$$

Gbr 9. Kutipan jawaban RS-14 tentang konsep kelembaman.

$$
\begin{aligned}
& \text { Mana, percepatan benda } \\
& \text { yang diamatt olch } \\
& \text { pengamat di atas } \\
& \text { tanah adalah benda } \\
& \text { tersehut bergerah. } \\
& \text { kavena jilua hita bevadu } \\
& \text { di dalam heveta bersama } \\
& \text { bonda tersenut maka pengamaran } \\
& \text { hita adalah benda tersebut } \\
& \text { diam. Sedanghan jine } \\
& \text { Wita dari loar levera yg } \\
& \text { herjalan molua pengamatan } \\
& \text { wita benda tersebor bergepak }
\end{aligned}
$$

Gbr 10. Kutipan jawaban RS-14 tentang konsep kelembaman.

$$
\begin{aligned}
& \text { Mobil yang gaya rotalma } \\
& \text { lebih besar adalar mobil A } \\
& \text { karena hecepatar mobil } \\
& \text { A lebih besar davi lecepatar } \\
& \text { monil B. }
\end{aligned}
$$

Gbr 11. Kutipan jawaban RS-14 tentang konsep kelembaman.

Dari kutipan jawaban dapat dinyatakan bahwa RS-14 kurang memahami maksud untuk konsep kelembaman dari masing-masing konteks diatas. $\mathrm{Hal}$ itu disebabkan karena RS-14 tidak menguasai konsep kelembaman. Hasil yang diperoleh sesuai dengan penelitian yang 
dilakukan sebelumnya oleh Yerdelen dan Damar [8] yang menyimpulkan bahwa tidak satupun dari siswa SMA yang benar-benar memahami konsep kelembaman.

Untuk responden RS-18 menjawab salah untuk konsep kelembaman pada saat kita mengendarai motor yang sedang bergerak dan direm secara tiba-tiba, seorang pengamat di atas tanah yang mengamati benda di dalam kereta api, dan peristiwa mobil A dan B yang memiliki kecepatan yang tetap. Berikut potongan jawaban responden dapat disajikan pada $\mathrm{Gbr} 12, \mathrm{Gbr} 13$, dan Gbr 14.

$$
\begin{aligned}
& \text { karena manusia sudah } \\
& \text { berada di momen inersia } \\
& \text { yaitu dia sudah nyaman } \\
& \text { berada diposisinya sehingga } \\
& \text { ketika motor berjalan tubuh } \\
& \text { akan terdorong ke depan } \\
& \text { dan ketika motor di rem } \\
& \text { tubuh akan terdorong ke belakang }
\end{aligned}
$$

Gbr 12. Kutipan jawaban RS-18 tentang konsep kelembaman.

\section{Percepatan benda yang berubah karena pengamat$$
\text { mengamatinya dari luar }
$$$$
\text { kereta api }
$$

Gbr 13. Kutipan jawaban RS-18 tentang konsep kelembaman.

$$
\begin{aligned}
& \text { Mobil A lebih besar gayanya } \\
& \text { kare na mobil A memirilki } \\
& \text { kecepatan yang lebih besar }
\end{aligned}
$$

Gbr 14. Kutipan jawaban RS-18 tentang konsep kelembaman.

Dari kutipan jawaban dapat dinyatakan bahwa RS-18 kurang memahami konsep kelembaman sehingga menyebabkan terjadi kekeliruan dalam menjawab soal. Kemungkinan disebabkan oleh kurangnnya pemahaman terhadap soal konsep. Hasil yang diperoleh sesuai dengan penelitian yang dilakukan Kevin [9] bahwa penyebab dari pemahaman konsepsi siswa yang rendah yaitu siswa susah untuk memahami soal yang berhubungan dengan pemahaman konsep.

Untuk responden RS-23 menjawab salah untuk konsep kelembaman pada peristiwa mobil A dan B yang memiliki kecepatan yang tetap, dan benda yang memiliki ukuran sama tetapi yang satu terbuat dari kayu dan yang lain terbuat dari besi. Berikut potongan jawaban responden dapat disajikan pada Gbr 15, dan Gbr 16.

$$
\begin{aligned}
& \text { mobil A karena no kecepatan } \\
& \text { mobil A sebesar } 150 \mathrm{~km} \text { ljam } \\
& \text { sehingga dapat disimpulkan } \\
& \text { gaya total mobil A lebih } \\
& \text { besar dari mobil B }
\end{aligned}
$$

Gbr 15. Kutipan jawaban RS-23 tentang konsep kelembaman.

$$
\begin{aligned}
& \text { karena massa senis besi } \\
& \text { lebin besar dibandingkan } \\
& \text { boay u, seningga besi } \\
& \text { memerlukan gaya yang lebin } \\
& \text { besar. }
\end{aligned}
$$

Gbr 16. Kutipan jawaban RS-23 tentang konsep kelembaman.

Dari kutipan jawaban dapat dinyatakan bahwa RS-23 kurang memahami maksud untuk konsep kelembaman dari masing-masing konteks diatas. Hal itu disebabkan karena RS-23 tidak menguasai konsep kelembaman. Hasil yang diperoleh sesuai dengan penelitian yang dilakukan sebelumnya oleh Yerdelen dan Damar [8] yang menyimpulkan bahwa tidak satupun dari siswa SMA yang benar-benar memahami konsep kelembaman.

\section{$>\quad$ Responden Kategori Rendah}

Responden kategori rendah RR-08, RR-15, dan RR-29 dapat mengerjakan soal konsep kelembaman untuk konsep berbeda. Hasilnya menunjukan untuk responden RR-08 menjawab salah untuk konsep kelembaman pada seorang pengamat di atas tanah yang mengamati benda di dalam kereta api, peristiwa mobil A dan B yang memiliki kecepatan yang tetap, Berikut potongan jawaban responden dapat disajikan pada Gbr 17. 


\section{Mobil A rebih besar gayanta \\ Karena mobul a memilli \\ kecepatan yg tebih besat}

Gbr 17. Kutipan jawaban RR-08 tentang konsep kelembaman.

Dari kutipan jawaban dapat dinyatakan bahwa RR-08 kurang memahami konsep kelembaman sehingga menyebabkan terjadi kekeliruan dalam menjawab soal. Kemungkinan disebabkan oleh kurangnnya pemahaman terhadap soal konsep. Hasil yang diperoleh sesuai dengan penelitian yang dilakukan Kevin [9] bahwa penyebab dari pemahaman konsepsi siswa yang rendah yaitu siswa susah untuk memahami soal yang berhubungan dengan pemahaman konsep.

Responden RR-15 menjawab salah untuk konsep kelembaman pada saat kita mengendarai motor yang sedang bergerak dan direm secara tiba-tiba, seorang pengamat di atas tanah yang mengamati benda di dalam kereta api, dan peristiwa mobil $A$ dan $B$ yang memiliki kecepatan yang tetap. Berikut potongan jawaban responden dapat disajikan pada Gbr 18, Gbr 19, dan Gbr 20.

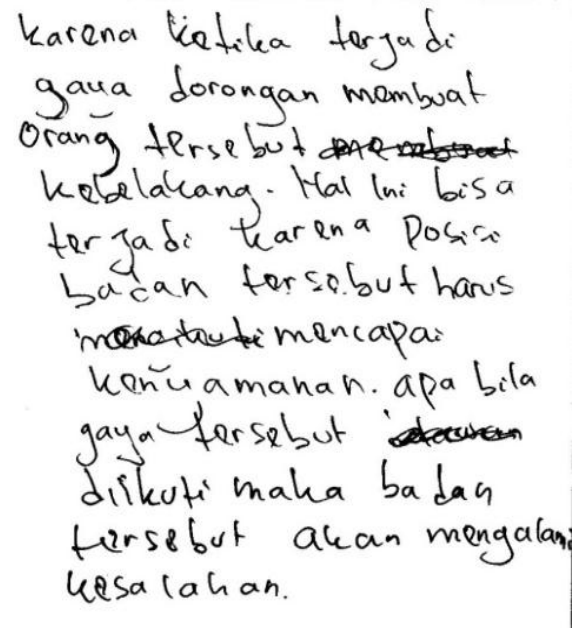

Gbr 18. Kutipan jawaban RR-15 tentang konsep kelembaman.

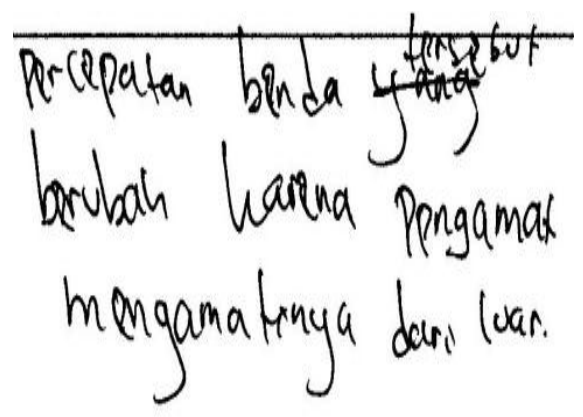

Gbr 19. Kutipan jawaban RR-15 tentang konsep kelembaman.

$$
\begin{aligned}
& \text { Dik: } \quad V_{1}=150 \mathrm{um} / \mathrm{Jan} \\
& v_{2}=75 \mathrm{~km} / \mathrm{Jam} \\
& 9=10 \mathrm{ki} \\
& \text { Jawa b } i_{1}=\frac{150}{10}=15 \\
& v_{2}=\frac{75}{10}=7.5 \\
& \begin{array}{c}
\text { Jadr. gayer fotal yang } \\
\text { bes ar a daloh }
\end{array} \\
& \text { mobd A }
\end{aligned}
$$

Gbr 20. Kutipan jawaban RR-15 tentang konsep kelembaman.

Dari kutipan jawaban dapat dinyatakan bahwa RR-15 kurang memahami maksud untuk konsep kelembaman dari masing-masing konteks di atas. Hal itu disebabkan karena RR-15 tidak menguasai konsep kelembaman. Hasil yang diperoleh sesuai dengan penelitian yang dilakukan sebelumnya oleh Yerdelen dan Damar [8] yang menyimpulkan bahwa tidak satupun dari siswa SMA yang benar-benar memahami konsep kelembaman.

Untuk responden RR-29 menjawab salah untuk konsep kelembaman pada peristiwa mobil A dan B yang memiliki kecepatan yang tetap, dan benda yang memiliki ukuran sama tetapi yang satu terbuat dari kayu dan yang lain terbuat dari besi. Berikut potongan jawaban responden dapat disajikan pada Gbr 21, dan Gbr 22.

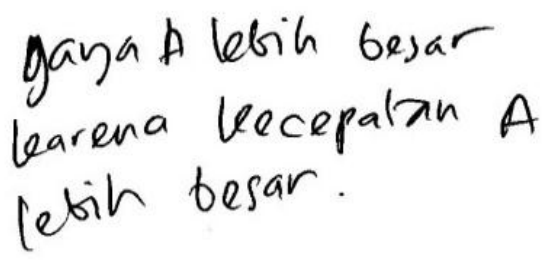

Gbr 21. Kutipan jawaban RR-29 tentang konsep kelembaman.
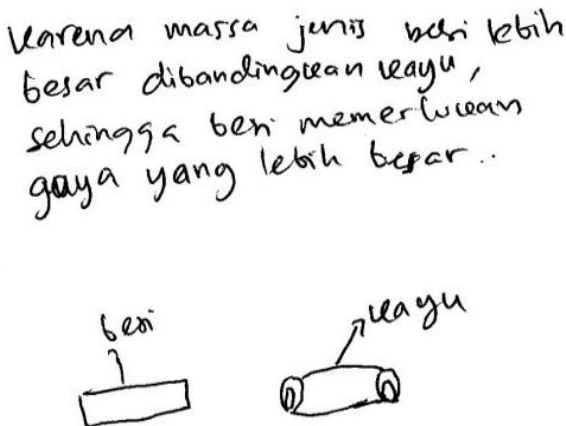

Gbr 22. Kutipan jawaban RR-29 tentang konsep kelembaman.

Dari kutipan jawaban dapat dinyatakan bahwa RR-29 kurang memahami maksud untuk konsep kelembaman dari masing-masing konteks diatas. Hal itu disebabkan karena RS-23 tidak 


\section{Jurnal Pendidikan Fisika Tadulako Online (JPFT) \\ Vol. 6 No. 2 \\ p-ISSN 2338-3240, e-ISSN 2580-5924}

menguasai konsep kelembaman. Hasil yang diperoleh sesuai dengan penelitian yang dilakukan sebelumnya oleh Yerdelen dan Damar [8] yang menyimpulkan bahwa tidak satupun dari siswa SMA yang benar-benar memahami konsep kelembaman.

Berdasarkan hasil analisa pada konsepsi siswa tentang kelembaman untuk konteks berbeda, responden memiliki pemahaman konsep yang beragam. penelitian yang telah dilakukan pada sembilan responden dalam tiga kelompok kategori yaitu kategori tinggi RT-07, RT-10, dan RT-26, kategori sedang RS-14, RS-18, dan RS23, dan kategori rendah RR-08, RR-15, dan RR29. Hasilnya menunjukkan konsepsi siswa pada materi kelembaman untuk konteks yang berbeda masih kurang.

Hasil penelitian yang dilakukan oleh Yerdelen dan Damar [8] menyimpulkan bahwa tidak satupun dari responden yang benar-benar memahami konsep kelembaman. Keadaan ini juga sesuai dengan penelitian yang dilakukan pada konsepsi siswa pada konsep kelembaman untuk konteks berbeda.

Pada penelitian ini juga siswa kurang memahami soal-soal pemahaman konsep, keadaan ini terjadi karena siswa lebih dominan diberikan soal perhitungan dibanding soal pemahaman konsep.

Hasil yang diperoleh sesuai dengan penelitian yang dilakukan Kevin [9] bahwa penyebab dari pemahaman konsep siswa yang rendah yaitu siswa susah untuk memahami soal yang berhubungan dengan pemahaman konsep.

\section{KESIMPULAN DAN SARAN}

Berdasarkan analisis data yang telah dilakukan pada konsepsi yang dimiliki siswa materi kelembaman untuk konteks berbeda yang diberikan dalam bentuk essay tes sebanyak 5 nomor, dapat disimpulkan bahwa kategori tinggi RT-07, RT-10, dan RT-26, kategori sedang RS14, RS-18, dan RS-23, dan kategori rendah RR08, RR-15, dan RR-29 hasilnya menunjukkan konsepsi siswa pada materi kelembaman untuk konteks yang berbeda masih tergolong rendah.

\section{DAFTAR PUSTAKA}

[1] Giancoli, D.C. (2001). Fisika Edisi Kelima Jilid II. Jakarat: Erlangga.

[2] Doctor, J. L. \& Mestre J. P. (2014). "Synthesis of Discipline-Based Education Research in Physics". Physical Review Special Topic Physics Education Research. 10, 020119

[3] Suwarto. (2013). Pengembangan Tes Diagnostik dalam Pembelajaran Panduan Praktis Bagi Pendidik dan Calon Pendidik. Yogyakarta: Pustaka Pelajar.

[4] Suparno, P. (2005). Miskonsepsi dan Perubahan Konsep dalam Pendidikan Fisika. Jakarta: PT. Grasindo.

[5] Pujianto, A. et al. (2013). "Analisis Konsepsi Siswa Pada Konsep Kinematika". Jurnal Pendidikan Fisika Tadulako. $1,(1), 16-21$.

[6] Nugraha, A. (2014). Deskripsi Konsepsi Siswa Tentang Rangkaian Listrik Arus Searah. Skripsi FKIP Untad Palu: tidak diterbitkan.

[7] Sukmadinata, N. (2010). Metode Penelitian Pendidikan. Bandung: PT. Remaja Rosda karya.

[8] Yerdelen, Sevda \& Damar. (2015). "Obstacles to Reasoning about Inertia in Different Contexts". European J of Physics Education. 6, 31-40.

[9] Saripah, K. M. (2014). Analisis Pemahaman Siswa Tentang Momen Inersia Pada Siswa Kelas XI SMA Negeri 1 Biromaru. Skripsi FKIP Untad Palu: tidak diterbitkan. 